\title{
Discovery of new human $\beta$-defensins using a genomics-based approach
}

\author{
Hong Peng Jia ${ }^{\mathrm{a}, 1}$, Brian C. Schutte ${ }^{\mathrm{a}, \mathrm{b}, 1}$, Andreas Schudy ${ }^{\mathrm{e}, 1}$, Rose Linzmeier ${ }^{\mathrm{f}}$, Janet \\ M. Guthmiller ${ }^{\mathrm{d}}$, Georgia K. Johnson ${ }^{\mathrm{d}}$, Brian F. Tack ${ }^{\mathrm{c}}$, Joseph P. Mitros ${ }^{\mathrm{a}, \mathrm{b}}$, Andre Rosenthal ${ }^{\mathrm{e}, 2}$, \\ Tomas Ganz ${ }^{\mathrm{f}, 2}$, Paul B. McCray Jr ${ }^{\mathrm{a}, \mathrm{b}, *, 2}$ \\ ${ }^{a}$ Department of Pediatrics, University of Iowa College of Medicine, Iowa City, IA, USA \\ ${ }^{\mathrm{b}}$ Genetics Ph.D. Program, University of Iowa College of Medicine, Iowa City, IA, USA \\ ${ }^{\mathrm{c}}$ Department of Microbiology, University of Iowa College of Medicine, Iowa City, IA, USA \\ ${ }^{\mathrm{d}}$ University of Iowa College of Dentistry, Iowa City, IA, USA \\ ${ }^{\mathrm{e}}$ Genome Sequencing Centre, Institute for Molecular Biotechnology, Jena, Germany \\ ${ }^{\mathrm{f}}$ Departments of Medicine and Pathology and the Will Rogers Institute for Pulmonary Research, UCLA School of Medicine, Los Angeles, CA, USA
}

Received 10 August 2000; received in revised form 8 November 2000; accepted 24 November 2000

Received by A. Dugaiczyk

\begin{abstract}
Epithelial $\beta$-defensins are broad-spectrum cationic antimicrobial peptides that also act as chemokines for adaptive immune cells. In the human genome, all known defensin genes cluster to a $<1 \mathrm{Mb}$ region of chromosome 8p22-p23. To identify new defensin genes, the DNA sequence from a contig of large-insert genomic clones from the region containing human $\beta$-defensin-2 (HBD-2) was analyzed for the presence of defensin genes. This sequence survey identified a novel $\beta$-defensin, termed HBD- 3 . The HBD- 3 gene contains two exons, is located $13 \mathrm{~kb}$ upstream from the HBD-2 gene, and it is transcribed in the same direction. A partial HBD-3 cDNA clone was amplified from cDNA derived from IL-1 $\beta$ induced fetal lung tissue. The cDNA sequence encodes for a 67 amino acid peptide that is $\sim 43 \%$ identical to HBD-2 and shares the $\beta$-defensin six cysteine motif. By PCR analysis of two commercial cDNA panels, HBD-3 expression was detected in adult heart, skeletal muscle, placenta and in fetal thymus. From RT-PCR experiments, HBD-3 expression was observed in skin, esophagus, gingival keratinocytes, placenta and trachea. Furthermore, in fetal lung explants and gingival keratinocytes, HBD-3 mRNA expression was induced by IL-1 $\beta$. Additional sequence analysis identified the HE2 (human epididymis secretory protein) gene $17 \mathrm{~kb}$ upstream from the HBD-3 gene. One splice variant of this gene (HE2 $\beta 1)$ encodes a $\beta$-defensin consensus cysteine motif, suggesting it represents a defensin gene product. HE2 $\beta 1$ mRNA expression was detected in gingival keratinocytes and bronchial epithelia using RT-PCR analysis. The discovery of these novel $\beta$-defensin genes may allow further understanding of the role of defensins in host immunity at mucosal surfaces. (C) 2001 Elsevier Science B.V. All rights reserved.
\end{abstract}

Keywords: Bacterial artificial chromosome; Interleukin-1 $\beta$; NFkB; Contiguous sequence; Chromosome 8

\section{Introduction}

The $\beta$-defensin gene family encodes cationic peptides that comprise part of the innate immune system (Lehrer et al., 1998). There are two classes of defensin genes, $\alpha$ and $\beta$, that differ in their disulfide bond pairing, genomic organization, and in their tissue distributions. In humans, the $\alpha$ -

\footnotetext{
Abbreviations: BAC, bacterial artificial chromosome; Contig, contiguous sequence; IL-1 $\beta$; Interleukin-1 $\beta$; HE2, human epidymis secretory protein

* Corresponding author. Department of Pediatrics, University of Iowa Hospitals and Clinics, 200 Hawkins Drive, Iowa City, IA 52242, USA. Tel.: +1-319-356-4866; fax: +1-319-356-7171.

E-mail address: paul-mccray@uiowa.edu (P.B. McCray Jr).

${ }^{1}$ These authors contributed equally to this work.

${ }^{2}$ Senior authors.
}

defensins are expressed in neutrophils (HDEFA1, HDEFA3, HDEFA4) and Paneth cells and other epithelia (HDEFA5, HDEFA6), and the $\beta$-defensins (HBD-1 and HBD-2) are expressed in epithelia (Ganz and Weiss, 1997; Huttner and Bevins, 1999). In addition to their broad spectrum antimicrobial properties, there is evidence that the $\beta$-defensins act as chemokines for immature dendritic cells and memory $\mathrm{T}$ cells, and thus may serve as an important bridge between the innate and adaptive immune systems (Yang et al., 1999). To date, two $\beta$-defensins of epithelial origin, HBD-1 and HBD-2, have been identified and characterized in humans (Bensch et al., 1995; Harder et al., 1997a). HBD-1 is constitutively expressed in the kidney, urogenital tract and other sites (Valore et al., 1998). In contrast, HBD-2 expression is induced by inflammatory 
stimuli such as IL-1 $\beta$ and the gene product is expressed in the skin, lung, mouth, intestine and other tissues (Harder et al., 1997a; Singh et al., 1998; Mathews et al., 1999).

In the human genome, all known defensin genes cluster to a $<1 \mathrm{Mb}$ region of chromosome 8p22-p23 (Harder et al., 1997b; Liu et al., 1997, 1998; Linzmeier et al., 1999). The cDNAs and genomic sequences for HBD-1 and HBD-2 were identified after the peptides were first isolated from plasma or tissue sources using biochemical techniques (Bensch et al., 1995; Harder et al., 1997a). Based on the precedent in other species for the $\beta$-defensins to exist as large families in a gene cluster on a single chromosome (Ouellette et al., 1989; Bevins et al., 1996; Iannuzzi et al., 1996; Liu et al., 1997), we hypothesized that it is likely there are other defensin-encoding sequences in the human genome. To identify new defensins, a genomics-based strategy was employed. We are constructing a contig across the defensin gene cluster by identifying and sequencing bacterial artificial chromosomes (BACs) that span the human defensin locus on 8p22-23. This report describes our initial success in using this approach to identify new human $\beta$ defensins.

\section{Materials and methods}

\subsection{Genomics-based approach for the identification of novel human $\beta$-defensins}

A human BAC library (CITB-978SK-B and CITB-HSP-C, Cat. \# 96011, Research Genetics, Huntsville, AL) was screened by PCR using primers designed to the human $\beta$ defensin-2 cDNA (Liu et al., 1998). BACs that were positive by PCR for the HBD-2 gene were then sequenced (Genome Sequencing Centre, Institute of Molecular Biotechnology, Jena, Germany, http://genome.imb-jena.de/). To generate a continuous DNA sequence, the sequences from the BAC clones containing HBD-2 were aligned using the Sequencher program (Gene Codes Corporation, Ann Arbor, MI).

The sequence from each BAC clone was analyzed for novel $\beta$-defensin genes utilizing the BLASTp program from the NCBI website (http://www.ncbi.nlm.nih.gov/ BLAST/). First, genomic BAC sequence was translated in all six possible reading frames using the ExPASy website (http://expasy.hcuge.ch/) and then compared to the protein sequences encoded by the HNP-1 and HBD-2 genes as representatives of the $\alpha$ - and $\beta$-defensins. The identification of novel defensins was based on the presence of the conserved six cysteine motifs characteristic of the $\alpha$ - (C$\left.\mathrm{X}-\mathrm{C}-\mathrm{X}_{4}-\mathrm{C}-\mathrm{X}_{9}-\mathrm{C}-\mathrm{X}_{9}-\mathrm{C}-\mathrm{C}\right)$ and $\beta$-defensins $\left(\mathrm{C}-\mathrm{X}_{6}-\mathrm{C}-\mathrm{X}_{4}-\mathrm{C}-\right.$ $\left.\mathrm{X}_{9}-\mathrm{C}-\mathrm{X}_{6}-\mathrm{C}-\mathrm{C}\right)$.

\subsection{Cell and tissue specimens}

Midgestation human fetal lung explants and adult gingival keratinocytes were cultured as reported previously (McCray et al., 1992; Mathews et al., 1999). Specimens from skin, esophagus, trachea and placenta were obtained from donor tissues or from surgical samples. The study was approved by the Institutional Review Board at the University of Iowa.

\subsection{Isolation of the cDNA for a novel $\beta$-defensin, human $\beta$ - defensin-3 (HBD-3)}

Human fetal lung explants were cultured in serum-free Waymouth's medium for $24 \mathrm{~h}$ with or without $100 \mathrm{ng} / \mathrm{ml} \mathrm{IL-}$ $1 \beta$ (R \& D Systems, Minneapolis, MN) (McCray et al., 1992). RNA was isolated from the explants and reverse transcribed to cDNA as previously described (McCray and Bentley, 1997). Primers were designed to flank the fulllength open reading frame for the HBD-3 cDNA, based on the putative exon sequence determined from the BAC sequences. RT-PCR was conducted using the following oligonucleotide primers: forward: 5'-ATGAGGATCCATTATCTTCT-3'; reverse: 5'-TTATTTCTTTCTTCGGCAGC- $3^{\prime}$. The first three nucleotides for each primer corresponds to the predicted start and stop codons, respectively. Each reaction contained approximately $1.25 \mathrm{pM}$ of the primers, $3 \mathrm{mM} \mathrm{Mg}^{2+}$, and $1 \mu \mathrm{l}$ of the RT reaction product for a total volume of $20 \mu \mathrm{l}$. An initial denaturing step $\left(95^{\circ} \mathrm{C}\right.$ for $3 \mathrm{~min}$ ), was followed by 30 cycles of denaturing $\left(94^{\circ} \mathrm{C}\right.$ for $\left.30 \mathrm{~s}\right)$, annealing $\left(60^{\circ} \mathrm{C}\right.$ for $\left.30 \mathrm{~s}\right)$, and extending $\left(72^{\circ} \mathrm{C}\right.$ for $\left.30 \mathrm{~s}\right)$, followed by $5 \mathrm{~min}$ at $72^{\circ} \mathrm{C}$ for elongation. The PCR product was cloned into the pBac PAK8 vector (Clontech, Palo Alto, CA) and transformed into DH5 $\alpha$ E. coli. Several positive colonies were selected and purified plasmid DNA was sequenced to confirm the HBD-3 cDNA sequence. Sequence ambiguities were resolved with the program Sequencher (Gene Codes Corporation).

\subsection{Tissue distribution of HBD-3 mRNA}

PCR was used to screen for HBD-3 mRNA expression in several tissues. Sample cDNA was purchased or generated from $1 \mu \mathrm{g}$ of total RNA from each sample by reverse transcription using random hexamer primers according to manufacturer's instructions (SuperScript transcription system, GibcoBRL). For screening analysis, a commercial cDNA panel of fetal and adult tissues was tested (human multiple tissue cDNA, Cat. \# K14220-1 and human fetal multiple tissue cDNA, Cat. \# K1425-1, Clontech, Palo Alto, CA). Further tissue specific studies were performed using RNA samples isolated from skin, an esophageal biopsy, primary cultures of gingival keratinocytes (Mathews et al., 1999), autopsy trachea (McCray and Bentley, 1997), and placental membranes.

Additional specific oligonucleotide primer sets were designed to the HBD-3 sequence and used for tissue distribution studies. The HBD-3 primers used were: forward: $5^{\prime}-$ TGTTTGCTTTGCTCTTCCTG- $3^{\prime}$; reverse: $5^{\prime}$-CTTTCTTCGGCAGCATTTTC- $3^{\prime}$. The predicted PCR product size was 179 bp. Each reaction contained approximately 
$1.25 \mathrm{pM}$ of the primers, $3 \mathrm{mM} \mathrm{Mg}^{2+}$, and $1 \mu \mathrm{l}$ of the RT reaction product for a total volume of $20 \mu \mathrm{l}$. An initial denaturing step $\left(95^{\circ} \mathrm{C}\right.$ for $\left.3 \mathrm{~min}\right)$, was followed by 30 cycles of denaturing $\left(94^{\circ} \mathrm{C}\right.$ for $\left.30 \mathrm{~s}\right)$, annealing $\left(60^{\circ} \mathrm{C}\right.$ for $\left.30 \mathrm{~s}\right)$, and extending $\left(72^{\circ} \mathrm{C}\right.$ for $\left.30 \mathrm{~s}\right)$, followed by $5 \mathrm{~min}$ at $72^{\circ} \mathrm{C}$ for elongation. The PCR products were separated by electrophoresis on a $2 \%$ agarose gel and visualized with ethidium bromide. As an internal control, GAPDH was also amplified in the reactions using the following primers: forward: $5^{\prime}-$ GTCAGTGGTGGACCTGACCT-3'; reverse: $5^{\prime}$-AGGGGTCTACATGGCAACTG- $3^{\prime}$. In selected specimens the specificity of the PCR amplification was confirmed by hybridization using a radiolabeled HBD-3 cDNA probe. RT-PCR products were separated on a $1.5 \%$ agarose gel, denatured in $0.5 \mathrm{~N} \mathrm{NaOH}$ for $1 \mathrm{~h}$ and then transferred to a nylon membrane (Hybond- ${ }^{+}$, Amersham) in $5 \mathrm{M} \mathrm{NaCl}$ and $0.5 \mathrm{~N} \mathrm{NaOH}$. The DNA was fixed to the membrane using an UV crosslinker and incubated in a prehybridization solution (high efficiency hybridization system, MRC) at $42^{\circ} \mathrm{C}$ for $4 \mathrm{~h}$. A HBD-3 fragment subcloned into the pBAK Pac8 vector (Clontech, Palo Alto, CA) was eluted and denatured, followed by ${ }^{32} \mathrm{P}-\mathrm{dCTP}$ labeling (Ready to Go DNA labeling Beads, Pharmacia Biotech). Hybridization was conducted at $42^{\circ} \mathrm{C}$ for $18 \mathrm{~h}$ in the same solution used for prehybridization. The blot was washed three times with $6 \mathrm{X} \mathrm{SSC} / 0.5 \%$ SDS at room temperature and then three times with $1 \times \mathrm{SSC} / 0.5 \% \mathrm{SDS}$ at $42^{\circ} \mathrm{C}$. The hybridization signal was visualized by autoradiography using lot Kodak X-OMAT film (Eastern Kodak, Rochester, NY) with intensifying screens at $80^{\circ} \mathrm{C}$.

\subsection{Identification of $\beta$-defensin motifs in members of the HE2 gene family}

Sequence analysis identified the HE2 gene on the $\beta$ defensin BAC contig. The HE2 gene consists of six alternatively spliced products from a single locus (Hamil et al., 2000). Our defensin homology searches identified that the HE2 $\beta 1$ sequence encodes a $\beta$-defensin motif. The intronexon boundaries of the HE2 gene locus were investigated by aligning the published HE2 mRNA sequences (Hamil et al., 2000) on the contig using the Sequencher program. In addition, PCR primer sets (Forward: 5'-TCGGAGAACTCAGGGAAAGA-3', Reverse: 5'-GCCCTTGGGATACTTCAACA- $3^{\prime}$ ) were designed to investigate the tissue expression patterns of HE $2 \alpha 1$ and HE2 $\beta 1$. These primer sets generated products of $417 \mathrm{bp}$ for HE2 $\alpha 1$ and $341 \mathrm{bp}$ for HE2 $\beta 1$. Each reaction contained approximately $1.25 \mathrm{pM}$ of the primers, $3 \mathrm{mM} \mathrm{Mg}^{2+}$, and $1 \mu \mathrm{l}$ of the RT reaction product for a total volume of $20 \mu \mathrm{l}$. An initial denaturing step $\left(95^{\circ} \mathrm{C}\right.$ for $\left.3 \mathrm{~min}\right)$, was followed by 35 cycles of denaturing $\left(94^{\circ} \mathrm{C}\right.$ for $\left.30 \mathrm{~s}\right)$, annealing $\left(57^{\circ} \mathrm{C}\right.$ for $\left.30 \mathrm{~s}\right)$, and extending $\left(72^{\circ} \mathrm{C}\right.$ for $30 \mathrm{~s}$ ), followed by $5 \mathrm{~min}$ at $72^{\circ} \mathrm{C}$ for elongation. The PCR products were separated by electrophoresis on a $2 \%$ agarose gel and visualized with ethidium bromide.

\section{Results}

\subsection{Identification of BAC clones that contain the $H B D-2$ gene}

The BAC library screening identified five clones positive for HBD-2 and a 'working draft' sequence was generated for them (Table 1). When the sequences for each of the five clones were aligned, the consensus sequence was divided into three contigs which spanned approximately $234 \mathrm{~kb}$ (Fig. 1). A similarity search identified several sequences from each clone with high homology to HBD-2. The sequences with highest homology were nearly identical to the previously published sequences for HBD-2 (Harder et al., 1997b; Liu et al., 1998). The only differences observed in the exons were a $\mathrm{C}$ to $\mathrm{T}$ silent substitution at position 84 from the ATG in the coding sequence and a $\mathrm{C}$ to $\mathrm{T}$ mutation at position 239 in the $3^{\prime}$ UTR. These results prove that the HBD-2 gene is located in these clones and suggests the presence of two single nucleotide polymorphisms in this gene.

\subsection{Identification of a novel $\beta$-defensin gene, $H B D-3$}

In addition to HBD-2, the similarity search also identified two other sequences that are predicted to encode peptides consistent with a $\beta$-defensin gene (Fig. 1). The first sequence was identical to the cDNA sequence for the previously cloned HE2 gene (see below) and the second was a novel gene that we designated human $\beta$-defensin-3 (HBD-3). HBD-3 is located $\sim 13 \mathrm{~kb}$ upstream from the HBD-2 gene and HE2 is located another $17 \mathrm{~kb}$ farther upstream. All three of these genes are transcribed in the same direction (Fig. 1). The intron exon boundaries for these genes are shown in Table 2. To confirm that the HBD-3 gene predicted by the analysis of the genomic sequence was expressed, mRNA analysis was performed. Since the expression of $\beta$-defensins can be inducible (Singh et al., 1998; Mathews et al., 1999), we screened for expression in a human lung tissue model in the presence or absence of pro-inflammatory stimuli. As shown in Fig. 2, a partial cDNA clone containing only the HBD-3 open reading frame was PCR amplified from cDNA derived from IL$1 \beta$ stimulated human fetal lung tissue. The sequence of the 204 bp PCR product (GenBank accession no. AF217245) contained a single open reading frame that encodes a 67 amino acid peptide that is $\sim 43 \%$ identical to HBD-2 and

Table 1

Status of sequence from BAC clones that contain the HBD-2 gene

\begin{tabular}{lllcl}
\hline BAC clone & GenBank acc. no. & Coverage & Contigs & Length $(\mathrm{kb})$ \\
\hline SCb-177k12 & AF252831 & 5.2 & 1 & $\sim 115$ \\
SCb-295j18 & AF252830 & 6.9 & 4 & $\sim 172$ \\
SCb-324n11 & AF189745 & 5.3 & 7 & $\sim 155$ \\
SCb-449o20 & AF285443 & 3.6 & 3 & $\sim 146$ \\
SCb-497j4 & AF202031 & 3.4 & 10 & $\sim 141$ \\
\hline
\end{tabular}



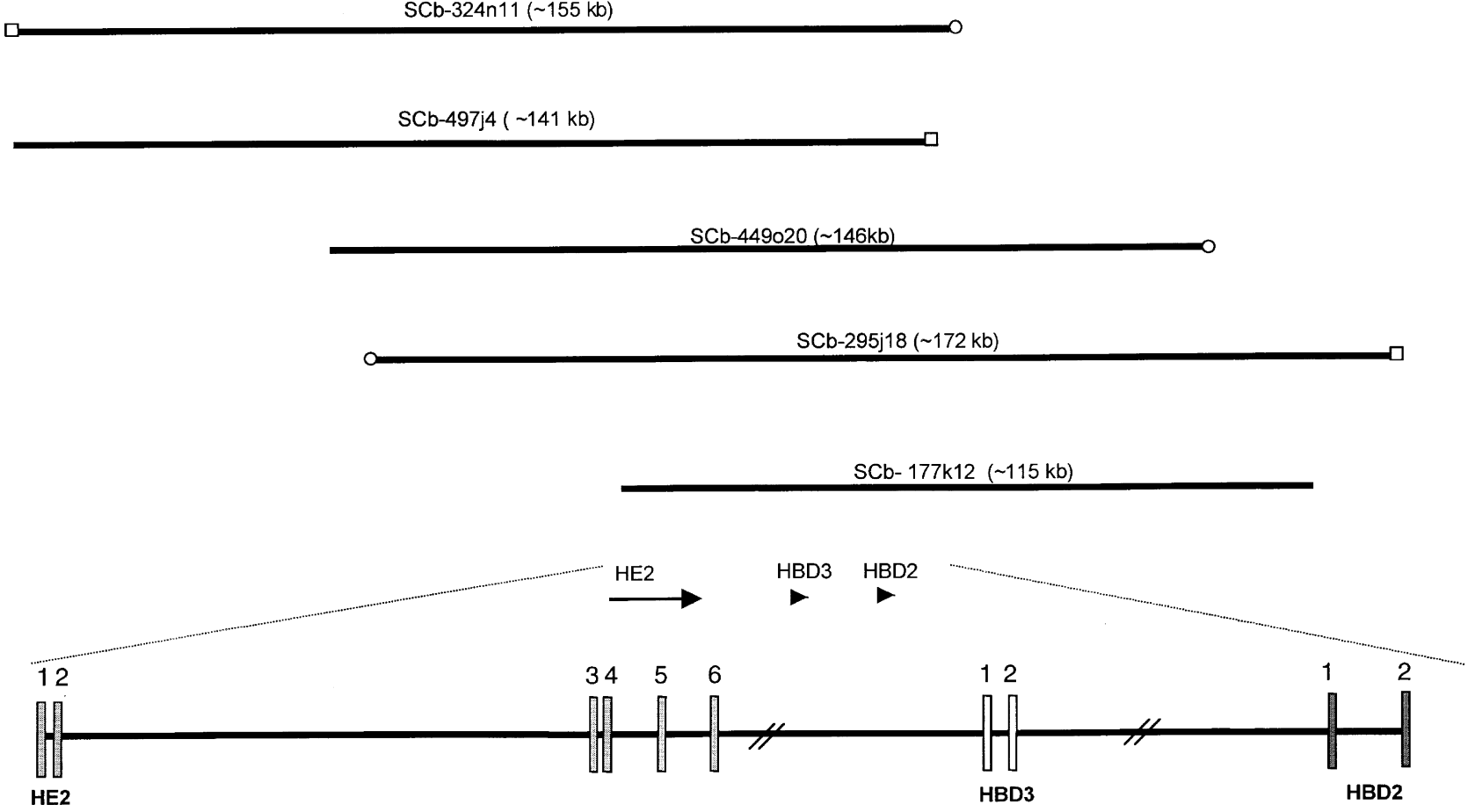

$3 \mathrm{~kb}$

Fig. 1. BAC clones derived from the human $\beta$-defensin gene locus containing HBD-2. Five clones positive for HBD-2 by PCR screening were sequenced and aligned to construct a $\sim 234 \mathrm{~kb}$ contig (see Section 3.1). The top thick line is the consensus sequence indicating two small gaps in the contig. The top left scale bar serves as a reference for this sequence. Below this each individual BAC clone and its length are noted. The T7 (open box) and SP6 (open circle) ends of the BACs are also noted. The bottom panel shows the relative orientation of coding regions for HBD-2 (dark rectangle), HBD-3 (open rectangle) and the HE2 (gray rectangle) genes and the directions of their transcription along the contig. The lower left scale bar serves as a reference to the bottom sequence.

faithfully shares the cysteine motif of the $\beta$-defensins (Fig. 3). This partial cDNA sequence was identical to the genomic sequence except for a 943 bp intervening sequence. Consensus splice sites are located at the ends of the intervening sequence demonstrating that it is an intron. These data demonstrate that HBD-3 is a real gene that consists of at least two exons (Table 2). No HBD-3 signal was detected from the midgestation lung tissue that was cultured in the absence of IL-1 $\beta$ (see below), suggesting that HBD-3 gene expression may be inducible. For other inducible defensins, NFKB consensus elements were reported near the gene (Harder et al., 1997b; Liu et al., 1998). In this case, no NFkB consensus elements were observed in $\sim 2900$ bp of sequence $5^{\prime}$ to the HBD-3 coding

Table 2

Exon/intron boundaries for the introns of the HBD-3 and HE2 genes. Exon sequence in indicated in upper case, intron sequence is in lower case. The numbers in the position column indicate the number of bases from the A nucleotide of the ATG start codon of the HBD-3 or HE2 cDNA sequences

\begin{tabular}{|c|c|c|c|c|}
\hline Intron & Position & $5^{\prime}-3^{\prime}$ Sequence at EXON/intron boundary & & \\
\hline \multicolumn{5}{|l|}{$H B D 3$} \\
\hline I & $58-59$ & TGTTCCAGgtaagatgggctgggaaatc & $\ldots \ldots$ & gtgctgttttgtcattgcagGTCATGGA \\
\hline \multicolumn{5}{|l|}{$H E 2$} \\
\hline I & $61-62$ & GTTTCCAGgtaaaatggaaaggtgaccC & ...... & gtgtgtttccacttgcacagGATCGTCT \\
\hline II & $214-215$ & TTACCAAGgtgagtcagggaccaacacg & $\ldots \ldots$ & ctccettgttecttctagTGCACATC \\
\hline III & $290-291$ & TGGGCCAGgtgagcattcataaaacaca & ...... & ctcttctgttgtatccatagGGGATGTT \\
\hline IV & $575-576$ & CСATTCTGgtgagaaaaagcgtgacatt & $\ldots \ldots$ & tttggcctcatgttcctcagAAATGAAA \\
\hline V & $679-680$ & TCCACCAGgtgagatggggaggatggga & $\ldots \ldots$ & ctgctcttatttgggaacagGGACAGGC \\
\hline
\end{tabular}




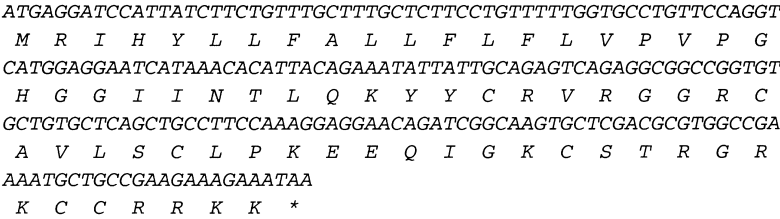

Fig. 2. cDNA sequence of human $\beta$-defensin-3 and the predicted translation product.

region. However, the region does have several consensus sequences for activator protein-1 (AP-1) response elements, gamma interferon response elements, GM-CSF response elements, and NF-IL-6 response elements, suggesting that HBD-3 gene expression may be regulated by inflammatory stimuli.

\subsection{Tissue distribution of HBD-3 $m R N A$}

As shown in Fig. 4A, PCR analysis of two commercial cDNA panels revealed HBD-3 mRNA expression in adult heart, skeletal muscle, and placenta, and in fetal thymus. HBD-3 expression in the placental sample was confirmed by isolating and sequencing the PCR product (data not shown). In another screening, an RNA dot blot (Multiple tissue expression array \#7775-1, Clontech) was probed with the partial HBD-3 cDNA. The mRNA signal was most readily detected in esophagus (data not shown). Further tissue specific RT-PCR studies were performed to determine sites of HBD-3 expression. Based on the data from the screening studies and our previous studies of $\beta$-defensin expression in pulmonary and oral mucosal sites, we chose to isolate RNA from skin, placental membranes, esophagus, and trachea. HBD-3 expression was readily detected in each of these tissues (Fig. 4B). The specificity of the PCR amplification was verified by hybridization using an HBD-3 cDNA probe in the trachea and gingival epithelium specimens (not shown). Furthermore, in fetal lung explants and cultured gingival keratinocytes, HBD-3 mRNA expression increased markedly following treatment with $100 \mathrm{ng} / \mathrm{ml} \mathrm{IL-1 \beta}$ for 24 $\mathrm{h}$. The PCR product generated from the IL-1 $\beta$ treated lung tissue explants was also isolated and sequenced to confirm that the product was indeed HBD-3 (Fig. 2).

\subsection{Identification of the HE2 gene locus in the defensin gene cluster}

Further analysis of the BAC clone sequences identified an additional gene containing a $\beta$-defensin peptide motif. A sequence similarity search with this sequence revealed regions that were identical to the previously identified gene HE2 (human epididymal secretory protein) (Kirchhoff et al., 1990; Krull et al., 1993; Osterhoff et al., 1994; Hamil et al., 2000). The HE2 gene produces six mRNA products (HE2 $\alpha 1, \mathrm{HE} 2 \alpha 2, \mathrm{HE} 2 \beta 1, \mathrm{HE} 2 \beta 2, \mathrm{HE} 2 \gamma 1$, and HE2 $\gamma 2$ ) by alternative splicing (Hamil et al., 2000). When aligned with the genomic sequences, these products were divided into six exons (Table 2). The sequence containing the $\beta$-defensin motif is located in exon 4 (Fig. 5). Of the six known splice variants, only the predicted protein sequence for HE2 $\beta 1$ contains this motif (Fig. 3). Outside of this region, the HE2 $\beta 1$ gene product shows little homology to the $\beta$-defensins and it is larger, containing more amino acids in the middle of the protein and at the C-terminus, than other $\beta$ defensins. The HE2 gene consists of six exons (Hamil et al., 2000 ), and the fourth exon of the HE locus is a 285 nucleotide cassette encoding the $\beta$-defensin six cysteine sequence (Tables 1 and 2, Fig. 5). In contrast to HBD-1, -2 and -3 , $\mathrm{HE} 2 \beta 1$ is a three exon gene with the second exon encoding sequence with no $\beta$-defensin homology and the location of the intervening sequences for HE2 $\beta 1$ does not resemble the $\beta$-defensin genes (Fig. 3). The HE $2 \alpha 1$ gene also contains the sequence that encodes the six cysteine motif, but it resides in the $3^{\prime}$ untranslated region of the gene (Fig. 5).

\subsection{HE2 $\beta 1$ mRNA expression in tissues outside the epididymis}

Limited RT-PCR analysis for HE2 $\beta 1$ expression was carried out using RNA derived from primary cultures of gingival keratinocytes and bronchial epithelia. A primer set was designed that included a forward primer from exon 2 and a reverse primer from exon 4 of HE2 (see Section 2.5). As shown in Fig. 4C, appropriate sized PCR products were amplified from both samples. These products were confirmed to be $\mathrm{HE} 2 \alpha 1$ and $\mathrm{HE} 2 \beta 1$ by sequencing (not shown).

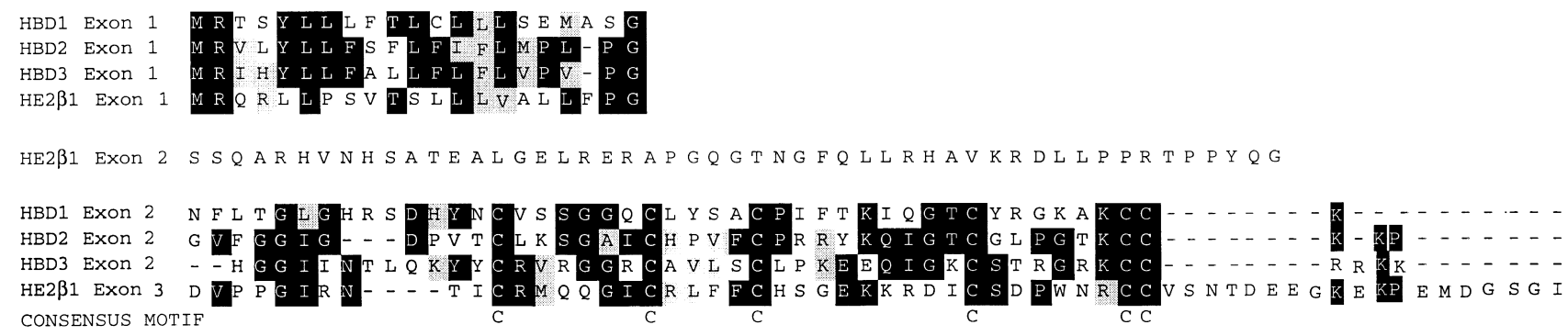

Fig. 3. Amino acid sequence alignment of HBD-3 and HE2 $\beta 1$ with other human $\beta$-defensin peptides $(\mathrm{HBD}=$ human $\beta$-defensin, HE2 $\beta 1=$ human epididymal secretory protein). Conserved amino acids are highlighted in black, conservative substitutions are noted in gray. Note the conserved six cysteine motif near the $\mathrm{C}$-terminal end. 


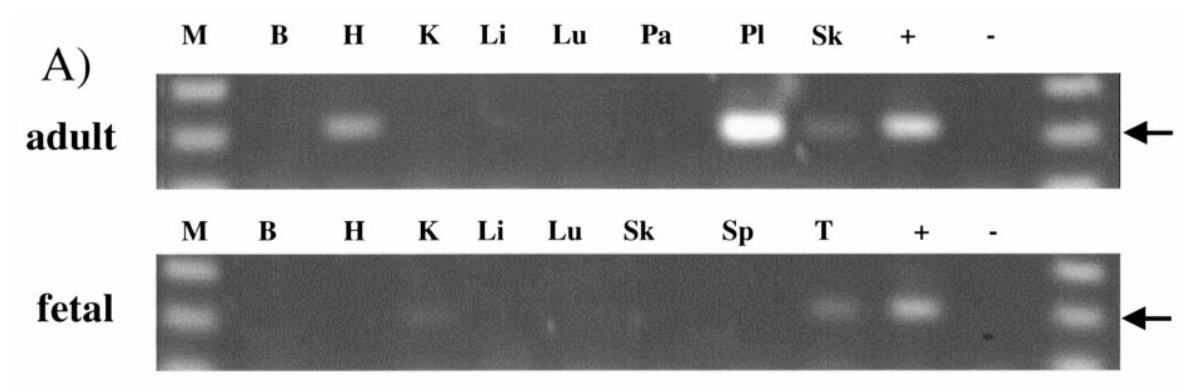

B)
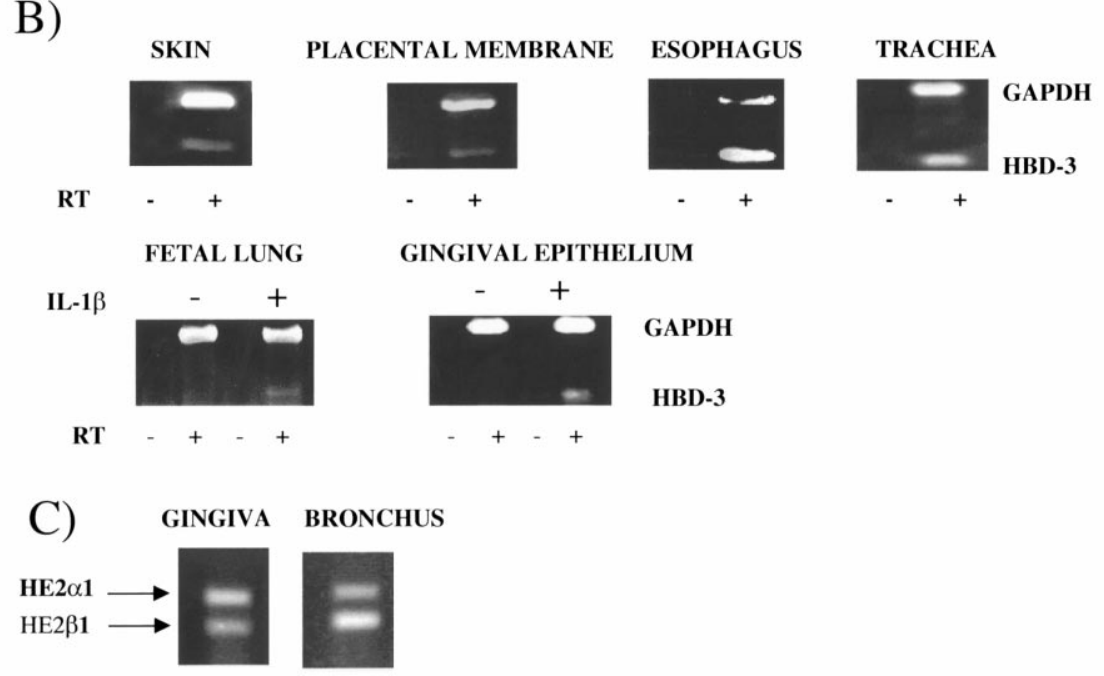

Fig. 4. Expression analysis of HBD-3 and HE2 genes. (A) Screening for HBD-3 mRNA expression in adult and fetal tissues using a multiple tissue cDNA panel. The expression of the HBD-3 gene was detected most easily in placenta (Pl), with modest signal present in adult heart (H) and skeletal muscle (Sk) and in fetal thymus (T). Arrows denote HBD-3 product. $\mathrm{M}=$ marker, $\mathrm{B}=$ brain, $\mathrm{K}=$ kidney, $\mathrm{Li}=$ liver, $\mathrm{Lu}=\mathrm{lung}$, Pa $=$ pancreas. Control samples were run with a mixture of all cDNA samples (+) and without any cDNA (-). (B) HBD-3 mRNA expression in several epithelial tissues as detected by RT-PCR. Signals for GAPDH control and HBD-3 indicated. In cultured gingival keratinocytes and fetal lung explants, expression was induced by $24 \mathrm{~h}$ treatment with IL-1 $\beta$. Samples were run with $(+)$ and without $(-)$ reverse transcriptase reaction (RT). (C) Expression of HE2 $\beta 1$ mRNA in oral and pulmonary epithelia. RT-PCR analysis was carried out as described in Section 2.5, using cDNA derived from primary cultures of gingival keratinocytes and bronchial epithelia as template. PCR products of the size predicted for HE2 $\alpha 1$ and HE2 $\beta 1$ were amplified from both samples and confirmed by sequencing.

\section{Discussion}

In this report, we successfully employed a genomicsbased approach to discover novel $\beta$-defensin genes within the human defensin locus. This strategy takes advantage of the fact that the defensin locus exists as a gene cluster, probably as the result of the duplication of an ancestral gene (Liu et al., 1997). Human $\beta$-defensin-3 represents the first new human defensin identified with this approach. Investigation of the expression of HBD-3 mRNA reveals a unique tissue distribution and evidence for induction by proinflammatory stimuli. In addition, we discovered that the HE2 gene resides within the defensin cluster and we recognized that one of the splice variants encodes a $\beta$-defensin sequence. Thus, this report confirms the validity of our methods and supports the feasibility of finding further novel genes in this cluster using this approach.

HBD-3 mRNA expression was detected in the esophagus, oral mucosa and trachea, all tissues with a similar endodermal embryonic origin. HBD-1 and HBD-2 are also expressed in the oral cavity (Krisanaprakornkit et al.,
1998; Mathews et al., 1999) and the lung (Bals et al., 1998; Singh et al., 1998) but to date, $\beta$-defensin expression in the human esophagus has not been reported. This tissue expression pattern is quite similar to that of mouse $\beta$-defensin-4 (Jia et al., 2000) (GenBank accession number AF155882). In addition, HBD-3 mRNA was detected in the placental membranes suggesting that the peptide may play a role in fetal-maternal defenses during pregnancy. HBD-3 mRNA was also detected in skin, as has been reported for HBD-2 (Harder et al., 1997a). Interestingly, HBD-3 mRNA expression in fetal lung explants and gingival keratinocytes was markedly induced by IL-1 $\beta$, despite the absence of NFKB consensus sequences in the immediate $5^{\prime}$ flanking sequence or intron of the gene. This suggests that IL-1 may be acting via other transcriptional regulatory pathways or that there are $\mathrm{NF} \kappa \mathrm{B}$ response elements that regulate HBD-3 expression from farther away, possibly the NFкB sites at the $5^{\prime}$ end of the HBD-2 gene (Liu et al., 1998).

The putative HBD-3 mature peptide sequence (GIINTLQKYYCRVRGGRCAVLSCLPKEEQIGKCSTRGRKCCRRKK) contains six more positively charged 


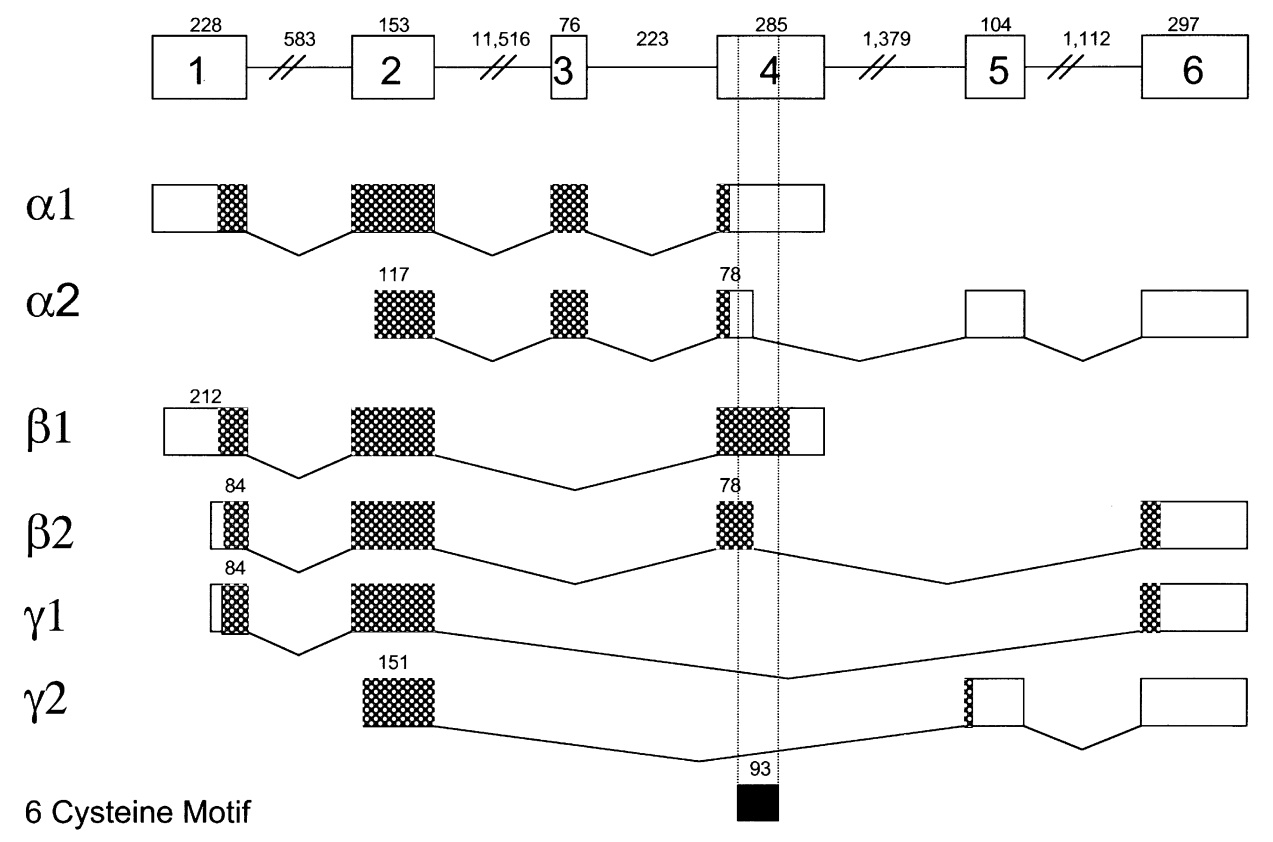

Fig. 5. Genomic organization of the HE2 gene locus. The exons were determined by aligning the published cDNA sequences (Hamil et al., 2000) along the genomic contig. Each of the six HE2 transcripts is derived from the alternative splicing of six exons. HE2 $\beta 1$ is a three exon gene product and contains a $\beta$ defensin six cysteine motif. The upper panel indicates the alignment of the six exons with their respective exon and intron sizes in nucleotides indicated. For each transcript, the white box indicates untranslated sequence, the gray box indicates coding sequence. The black box at the bottom indicates the location of the six cysteine defensin motif.

amino acids than either the HBD-1 or HBD-2 mature peptides (see Fig. 3). Presumably, the net positive charge state of a defensin peptide is an important determinant of its functional properties. It will be interesting to learn how the properties of the HBD-3 peptide compare with the other human $\beta$-defensins in terms of its antimicrobial activity and ability to function as a chemokine (Yang et al., 1999).

The defensin gene cluster is believed to have developed from the duplication of an ancestral gene (Liu et al., 1997), but it is not clear from this work whether the HE2 gene is related to this gene family. The most compelling evidence in favor of this hypothesis is that one of its splice variants, HE2 $\beta 1$, encodes a cationic peptide that has the six-cysteine motif that is characteristic of the $\beta$-defensin genes. Also, the protein sequence encoded by the first exons of HBD-1, -2 , and -3 and HE2 $\beta 1$ share significant homology and this exon terminates at a conserved glycine residue in all four genes. In addition, the HE2 gene is located in the defensin cluster on 8p23 near the HBD-2 and HBD-3 genes, and like other $\beta$-defensin genes, recent immunolocalization studies showed that the HE2 $\beta 1$ gene product is expressed in epithelia, in this case in the epididymis (Hamil et al., 2000). Furthermore, our expression analysis detected HE2 $\beta 1$ transcripts expressed in gingival keratinocytes and pulmonary epithelia, thus expanding the known tissue distribution of this gene product. To the contrary, the genomic structure of the HE2 $\beta 1$ variant is not consistent with the $\beta$-defensin genes. It has three exons while the $\beta$-defensin genes have two exons. One possible explanation for the additional exon is that the HE2 and defensin genes share a common origin, but that a new sequence was introduced into the intron between the original two exons. The new intervening sequence contained an exon that was then incorporated into the HE2 gene. Finally, we note that the genital tract is a recognized site of antimicrobial peptide expression in mammals (Quayle et al., 1998; Valore et al., 1998; Malm et al., 2000) and invertebrates (Samakovlis et al., 1991). If the HE2 $\beta 1$ gene is related to the defensin gene family we speculate that it may also play a role in host defense in this region. As with HBD-3, it will be important to evaluate the HE2 $\beta 1$ peptide for antimicrobial activity.

In previous studies we reported the construction of a $\sim 450 \mathrm{~kb}$ BAC contig containing the $\alpha$-defensin locus and HBD-1 (Liu et al., 1998; Linzmeier et al., 1999). Our current results build on this work by generating a new contig that contains other $\beta$-defensin genes. Based on previous sequence data, radiation hybrid mapping and FISH (Liu et al., 1997; Linzmeier et al., 1999), we conclude that the current contig containing HBD-2, HBD-3, and the HE2 gene family is more centromeric than the contig containing the $\alpha$-defensins and HBD- 1 . We estimate that there may be $\sim 500-600 \mathrm{~kb}$ of intervening sequence between the two contigs (Linzmeier et al., 1999). A future goal of this project is to complete the contig of clones across the entire defensin gene cluster and continue our search for novel defensin genes in this cluster. 


\section{Acknowledgements}

We acknowledge the support of NIH HL-61234 (PBM, BCS, and BFT), P30-HD27748 (Frank Morriss and BCS), HL-46809 (TG and RL), DE13334 (JMG, GKJ, BFT and PBM), and the Children's Miracle Network Telethon. We thank Tim Starner for assistance with the lung explant studies. We thank Margaret Malik, Andrea Vivado, Connie Organ and David Verbik for technical assistance. We acknowledge the support of the Cell Culture Core, partially supported by the Cystic Fibrosis Foundation, NHLBI (PPG HL-51670), and the Center for Gene Therapy for Cystic Fibrosis (NIH P30 DK-97-010). PBM is the recipient of a Career Investigator Award from the American Lung Association.

\section{References}

Bals, R., Wang, X., Wu, Z., Freeman, T., Bafna, V., Zasloff, M., Wilson, J.M., 1998. Human $\beta$-defensin 2 is a salt-sensitive peptide antibiotic expressed in human lung. J. Clin. Invest. 102, 874-880.

Bensch, K.W., Raida, M., Magert, H.J., Schulz-Knappe, P., Forssmann, W.G., 1995. hBD-1: a novel beta-defensin from human plasma. FEBS Lett. 368, 331-335.

Bevins, C.L., Jones, D.E., Dutra, A., Schaffzin, J., Muenke, M., 1996. Human enteric defensin genes: chromosomal map position and a model for possible evolutionary relationships. Genomics 31, 95-106.

Ganz, T., Weiss, J., 1997. Antimicrobial peptides of phagocytes and epithelia. Semin. Hematol. 34, 343-354.

Hamil, K.G., Sivashanmugam, P., Richardson, R.T., Grossman, G., Ruben, S.M., Mohler, J.L., Petrusz, P., O'Rand, M.G., French, F.S., Hall, S.H., 2000. HE2beta and HE2gamma, new members of an epididymis-specific family of androgen-regulated proteins in the human. Endocrinology $141,1245-1253$.

Harder, J., Bartels, J., Christophers, E., Schroder, J.-M., 1997a. A peptide antibiotic from human skin. Nature 387, 861-862.

Harder, J., Siebert, R., Zhang, Y., Matthiesen, P., Christophers, E., Schlegelberger, B., Schroder, J.-M., 1997b. Mapping of the gene encoding human $\beta$-defensin-2 (DEFB2) to chromosome region 8p22-p23.1. Genomics 46, 472-475.

Huttner, K.M., Bevins, C.L., 1999. Antimicrobial peptides as mediators of epithelial host defense. Pediatr. Res. 45, 785-794.

Iannuzzi, L., Gallagher, D.S., Di Meo, G.P., Diamond, G., Bevins, C.L., Womack, J.E., 1996. High-resolution FISH mapping of $\beta$-defensin genes to river buffalo and sheep chromosomes suggests a chromosome discrepancy in cattle standard karyotypes. Cytogenet. Cell Genet. 75, $10-13$.

Jia, H.P., Wowk, S.A., Schutte, B.C., Lee, S.K., Vivado, A., Tack, B.F., Bevins, C.L., McCray Jr, P.B., 2000. A novel murine $\beta$-defensin expressed in tongue, esophagus and trachea. J. Biol. Chem. 275, 33314-33320.

Kirchhoff, C., Osterhoff, C., Habben, I., Ivell, R., Kirchloff, C., 1990. Cloning and analysis of mRNAs expressed specifically in the human epididymis. Int. J. Androl. 13, 155-167.

Krisanaprakornkit, S., Weinberg, A., Perez, C.N., Dale, B.A., 1998. Expression of the peptide antibiotic human $\beta$-defensin 1 in cultured gingival epithelial cells and gingival tissue. Infect. Immun. 66, 42224228.

Krull, N., Ivell, R., Osterhoff, C., Kirchhoff, C., 1993. Region-specific variation of gene expression in the human epididymis as revealed by in situ hybridization with tissue-specific cDNAs. Mol. Reprod. Dev. 34, $16-24$.

Lehrer, R.I., Bevins, C.L., Ganz, T., 1998. Defensins and other antimicrobial peptides. In: Ogra, P.L., Mestecky, J., Lamm, M.E., Strober, W.M., Bienstock, J. (Eds.), Mucosal Immunology. Academic Press, New York, pp. 89-99.

Linzmeier, R., Ho, C.H., Hoang, B.V., Ganz, T., 1999. A 450-kb contig of defensin genes on human chromosome 8p23. Gene 233, 205-211.

Liu, L., Wang, L., Jia, H.P., Zhao, C., Heng, H.H.Q., Schutte, B.C., McCray Jr, P.B., Ganz, T., 1998. Structure and mapping of the human $\beta$-defensin HBD-2 gene and its expression at sites of inflammation. Gene 222, 237-244.

Liu, L., Zhao, C., Heng, H.H.Q., Ganz, T., 1997. The human $\beta$-defensin-1 and $\alpha$-defensins are encoded by adjacent genes: two peptide families with differing disulfide topology share a common ancestry. Genomics 43, 316-320.

Malm, J., Sorensen, O., Persson, T., Frohm-Nilsson, M., Johansson, B., Bjartell, A., Lilja, H., Stahle-Backdahl, M., Borregaard, N., Egesten, A., 2000. The human cationic antimicrobial protein (hCAP-18) is expressed in the epithelium of human epididymis. Is present in seminal plasma at high concentrations, and Is attached to spermatozoa. Infect. Immun. 68, 4297-4302.

Mathews, M.S., Jia, H.P., Guthmiller, J.M., Losh, G., Graham, S., Johnson, G.K., Tack, B.F., McCray Jr, P.B., 1999. Production of beta-defensin antimicrobial peptides by the oral mucosa and salivary glands. Infect. Immun. 67, 2740-2745.

McCray Jr, P.B., Bentley, L., 1997. Human airway epithelia express a $\beta$ defensin. Am. J. Respir. Cell. Mol. Biol. 16, 343-349.

McCray Jr, P.B., Reenstra, W.W., Louie, E., Johnson, J., Bettencourt, J.D., Bastacky, J., 1992. Expression of CFTR and presence of cAMPmediated fluid secretion in human fetal lung. Am. J. Physiol. 262, L472-L481.

Osterhoff, C., Kirchhoff, C., Krull, N., Ivell, R., 1994. Molecular cloning and characterization of a novel human sperm antigen (HE2) specifically expressed in the proximal epididymis. Biol. Reprod. 50, 516-525.

Ouellette, A.J., Pravtcheva, D., Ruddle, F.H., James, M., 1989. Localization of the cryptdin locus on mouse chromosome 8. Genomics 5, 233-239.

Quayle, A.J., Porter, E., Nussbaum, A.A., Wang, Y.M., Brabec, C., Yip, K.P., Mok, S.C., 1998. Gene expression, immunolocalization, and secretion of human defensin-5 in human female reproductive tract. Am. J. Pathol. 152, 1247-1258.

Samakovlis, C., Kylsten, P., Kimbrell, D.A., Engstrom, A., Hultmark, D., 1991. The andropin gene and its product, a male-specific antibacterial peptide in Drosophila melanogaster. EMBO J. 10, 163-169.

Singh, P.K., Jia, H.P., Wiles, K., Hesselberth, J., Liu, L., Conway, B.D., Greenberg, E.P., Valore, E.V., Welsh, M.J., Ganz, T., Tack, B.F., McCray Jr, P.B., 1998. Production of $\beta$-defensins by human airway epithelia. Proc. Natl. Acad. Sci. USA 95, 14961-14966.

Valore, E.V., Park, C.H., Quayle, A.J., Wiles, K.R., McCray Jr, P.B., Ganz, T., 1998. Human $\beta$-defensin-1, an antimicrobial peptide of urogenital tissues. J. Clin. Invest. 101, 1633-1642.

Yang, D., Chertov, O., Bykovskaia, S.N., Chen, Q., Buffo, M.J., Shogan, J., Anderson, M., Schroder, J.M., Wang, J.M., Howard, O.M., Oppenheim, J.J., 1999. Beta-defensins: linking innate and adaptive immunity through dendritic and T cell CCR6. Science 286, 525-528. 